Agro-Science Journal of Tropical Agriculture, Food, Environment and Extension Volume 18 Number 1 (January 2019) pp. 50-55

ISSN 1119-7455

\title{
FARM-LEVEL DETERMINANTS OF ACCESS TO LAND BY ARABLE CROP FARMERS IN IKWUANO LOCAL GOVERNMENT AREA OF ABIA STATE, NIGERIA
}

\author{
${ }^{1}$ Onya S.C., ${ }^{1}$ Ugochukwu G.C. and ${ }^{2}$ Ejiba I.V. \\ ${ }^{1}$ Department of Agricultural Economics, \\ Michael Okpara University of Agriculture, Umudike, Abia State, Nigeria \\ ${ }^{2}$ Department of Agricultural Economics, University of Ibadan, Ibadan, Nigeria \\ *Corresponding author's email: simeononya@yahoo.com
}

\begin{abstract}
This study was carried out to examine the farm-level determinants of access to land by arable crop farmers in Ikwuano Local Government Area of Abia State, Nigeria. A multistage sampling technique was used to select 80 arable crop farmers from four autonomous communities. Data were analysed using descriptive statistics and Logit regression model. Result from the descriptive statistics showed that (55\%) of the farmers were male headed, majority of the farmers had secondary education; while farm size was relatively low. With respect to the methods of land ownership and acquisition, the result revealed that majority of the lands for arable crop farming were owned or acquired through inheritance (92.5\%), communal (72.5\%) and purchase (50\%) respectively. Consequently, the level of access to land for arable crop farming showed that $42 \%$ of respondents had moderate access, $35 \%$ had high access, while $22 \%$ had low access to land for arable crop farming. The result of the logit regression indicated that age, sex, household size, number of years spent in school, cooperative membership and credit amount significantly influenced access to land by arable crop farmers. Communal land ownership and male dominance were identified as constraints to access to land for arable crop farming in the study area. The study therefore, recommended strengthening of relevant institutions so as to enable farmers' access required land for arable crop farming without gender disparity.
\end{abstract}

Key words: farm-level, determinants, land access, arable crops and Logit

\section{INTRODUCTION}

The basis of agricultural production and the most important production factor for farmers is land. Land is a very strategic socio-economic asset, particularly in poor societies where wealth and survival are measured by control of, and access to land (Titilola and Jeje, 2008). Marie et al. (2014) noted that, land is the most important economic resources most particularly for developing countries with largely rural populations and most people earn a living through agriculture. It has remained an important factor of production since the creation of man and a fundamental factor of production in the agricultural sector all over the world and provides a basis for crop production in Nigeria and sub-Saharan Africa. Secure access to productive land is critical to millions of poor people living in rural areas and depending on agriculture, livestock or forests for their livelihood. It reduces their vulnerability to hunger and poverty; influences their capacity to invest in their productive activities and in the sustainable management of their resources; enhances their prospects for better livelihoods; and helps them develop more equitable relations with the rest of their society, thus contributing to justice, peace and sustainable development, International Fund for Agricultural Development, IFAD (2008). Access to land and tenure security have a marked effect on expectations of a return on an investment of both labour and capital and many development thinkers have attributed the weakened incentives to invest in agriculture to the poor access to land and land ownership title (Migot-Adholla and Bruce, 1994). If farmers do not have secured land rights, they will have few incentives to engage in sustainable agricultural production or to consider the long-term environmental impact of over-exploitation of land's nutrients (Oyekale, 2012). Mintzer (2010) and Henri-Ukoha et al. (2014) asserted that most farmers work on small parcels of land that are either leased to them or have been acquired through family bonds or purchase. But all too often, they are not given the means to produce as much as they want.

IFAD (2008) noted that rural poverty is strongly associated with poor access to land, either in the form of landlessness or because of insecure and contested land rights. Secure rights to land are 
also a source of financial security, as collateral to raise credit or as a transferable asset that can be sold, rented out, mortgaged, loaned or bequeathed. Moreover, secure access to land creates incentives for the user to invest labour and other resources in it, so as to maintain or enhance its value and sustain its productivity, and to access social and economic development opportunities.

Land access and tenure security has long been identified as one of the key elements necessary to bring about higher levels of investment and access to credit, for identifying agricultural production, facilitate reallocation of production, encouraging better natural resource management and sustainable development and allow economic diversification and growth. Lack of access to land through ownership or secured tenure affects agricultural productivity. If farmers do not have secured land rights, they will have little or no access to credit or the benefits of membership.

Therefore an understanding of the farm-level determinants of access to land among arable crop farmers will provide policy makers with information to improve land accessibility that can contribute to increasing food production potential among arable crop farmers. The study specifically examined the socioeconomic characteristics of arable crop farmers; identified the methods of land ownership and acquisition; estimated the level of access to land by arable crop farmers; estimated the determinants of access to land by arable crop farmers, and identified major constraints militating against land access and acquisition in the study area.

\section{MATERIALS AND METHODS}

The study was carried out in Ikwuano Local Government Area (LGA) of Abia State, Nigeria. The local government lies between longitudes $7.34^{\circ}$ and $7.56^{\circ} \mathrm{E}$ and Latitudes $5.26^{\circ}$ and $5.43^{\circ} \mathrm{N}$ in the tropical rainforest area of the south eastern Nigeria, and 122 metres above sea level. The local government has an area of $281 \mathrm{~km}^{2}$ and a population of 137,993 (NPC, 2006). It also has a land mass of about $600000 \mathrm{~km}^{2}$. It is made up of about 28 communities and is bounded by Ini LGA of Akwa Ibom State by the West and Umuahia North, on the North by Bende LGA and Umuahia South LGA, on the South by Itoro LGA of cross river state, and on the east by Ikono and Oforo LGAs in Akwa Ibom State. The people of Ikwuano engage mainly in farming, accounting for about $85 \%$ of the entire population while petty trading and transport business occupies the minor sector. Ikwuano has a vast area of arable land; her soil is very rich and good for agriculture. In most parts, the soils are of sandy loam to clay, well aerated and well drained. Major crop cultivated are cassava, rice, melon plantain, banana etc while livestock such as sheep, goat and poultry are reared in the area. A multi-stage sampling technique was employed in selecting 80 respondents for the study. The first stage involved the random selection of four autonomous communities from the LGA. The second stage involved the random selection of two villages from each selected community making a total of 8 villages for the study while the final stage involved the random selection of 10 arable crop farmers from each of the selected villages which gave a total sample of 80 arable crop farmers used for the study. Data for the analysis were obtained basically from primary sources. Data collected were analyzed using simple statistical tools such as means and percentages, as well as econometric model such as the Logistic regression model.

Logit regression model was employed to estimate the determinants of access to land by arable crop farmers in the study area. The functional form of logit model is specified as follows (Gujarati, 2004):

$$
\begin{aligned}
& P i=E\left(Y=\frac{1}{X i}\right)=\frac{1}{1+e^{-(\alpha+\beta X i)}}= \\
& \frac{1}{1+e^{-(Z i)}} \ldots \ldots \ldots \ldots \ldots \ldots \ldots \ldots \ldots \ldots \ldots \ldots \ldots \ldots \ldots \ldots \ldots \ldots \ldots
\end{aligned}
$$

For ease of exposition, the logit becomes a linear function of different explanatory variables:-

$$
\begin{aligned}
& L_{i}=\ln \left(\frac{P i}{1-P i}\right)=Z_{i}=\beta_{0}+\beta_{1} X_{1}+\beta_{2} X_{2 \ldots \ldots+} \\
& \beta_{9} X_{9} \ldots \ldots \beta_{n} X_{n} \ldots \ldots \ldots \ldots \ldots \ldots \ldots \ldots \ldots(2)
\end{aligned}
$$

where, $\mathrm{Y}$ is measured as:

$$
\frac{\text { Area of Land Farmed (ha) }}{\text { Area of Land Needed for Farming (ha) }},
$$

$P_{i}$ is the probability of having access to land,

$1-\mathrm{P}_{\mathrm{i}}$ is the probability of non- access to the land

$L_{i}$ is the logit,

$X_{i}$ is a vector of explanatory variables such as

$\mathrm{X}_{1}$ - Age (Years)

$\mathrm{X}_{2}-\operatorname{Sex}($ Male $=1$, Female $=0)$,

$\mathrm{X}_{3}$ - Household Size (Number)

$\mathrm{X}_{4}$ - Education (years)

$\mathrm{X}_{5}$ - Objective of farming $($ Commercial $=1$, Subsistence $=0$ )

$\mathrm{X}_{6}$ - Co-operative membership $($ Member $=1$,

Otherwise $=0$ )

$\mathrm{X}_{7}$ - Farming Experience (Years)

$\mathrm{X}_{8}$ - Annual Income ( $)$

$\mathrm{X}_{9}$ - Access to Credit (Yes = 1, Otherwise $=0$ )

$\beta_{n}$ is a vector of parameters to be estimated. It should be noted that the estimated coefficients do not directly indicate the effect of the change in the corresponding independent variables on probability (P) of the outcome occurring. Rather the coefficients indicate the effect of individual explanatory variables on its $\log$ of odds $L_{i}$ (Neupane et al., 2002). Therefore, to indicate the effect of explanatory variables on the odds, the odds ratio is an appropriate tool. 


\section{RESULTS AND DISCUSSION \\ The Socio-Economic Characteristics of the Respondents in the Study Area}

The socio-economic profile of arable crop farmers is shown in Table 1. The result showed that $(55 \%)$ of the farmers were male household heads while (45\%) were female household heads. This implies that arable crop farming in the study area is primarily male dominated. This could be due to the cultural and religious background of most African communities that still put women's enterprise under their husbands' care as a form of submission. This agrees with the study of Bamire (2010) and Tsue et al. (2014) on the effects of tenure and land use factors on food security among rural households in the dry savannas of Nigeria, where majority $(92.5 \%)$ of the respondents were males.

The age distribution of the respondents showed that 20\% were between 40-47 years, 58-54 years, and 55-61years, respectively; while $25 \%$ and $15 \%$ of them were between the ages of 34-47 and 27-33 years respectively. The mean age was 41.3 years which implies that majority of the farmers were within the active and economic age bracket of between 27-61years. The result agreed with the findings of Ogunwale (2000), Ezedinma and Otti (2001) and Tsue et al. (2014) that the mean age of farmers in Nigeria was between 45-48 years. The level of education of the farmers suggests that majority $(60 \%)$ of them attended secondary school, $15 \%$ of the respondents had primary education, $20 \%$ of them had tertiary education while $5 \%$ of them had no formal education. The mean years spent in school was 11.6 years implying that majority of the arable crop farmers in Ikwuano LGA had formal education and could read and write. Household size of the respondents showed that $40 \%$ of the arable crop farmers had household size of between 4 and 6 persons, $25 \%$ of the arable crop farmers had household size of between 1 and 3 persons, $20 \%$ had household size of between 7 and 9 members while $15 \%$ had household size of 10 and 12 members. The mean household size was 6 persons implying that arable crop farmers in the study area have moderate household size. With the moderate household size, it is expected that arable crop farmers should have access to the required land needed for farming in the study area. This tends to agree with Obamiro et al. (2003) who reported that the average number of people in a farm household was seven. The farm size distribution of the respondents showed that $40 \%$ had farm size of between 0.5-0.9 hectares, $25 \%$ had between 1-1.4 hectares, $23.75 \%$ had between $1.5-1.9$ hectares, while $2.5 \%$ and $8.75 \%$ of the respondents had between 2.0-2.4 hectares and 2.5-2.9 hectares, respectively with mean farm size of 1.28 hectares. This suggests that land-man ratio in the study area is below the national average of 2.5 hectares and that majority of the arable crop farmers are subsistence farmers.
Table 1: Socio-economic characteristics of the respondents

\begin{tabular}{|c|c|c|}
\hline Variable & Frequency & Percentage \\
\hline \multicolumn{3}{|l|}{ Sex (HH Head) } \\
\hline Male & 44 & 55 \\
\hline Female & 36 & 45 \\
\hline \multicolumn{3}{|l|}{ Age (HH Head) } \\
\hline $27-33$ & 12 & 15 \\
\hline $34-40$ & 20 & 25 \\
\hline $40-47$ & 16 & 20 \\
\hline $48-54$ & 16 & 20 \\
\hline $55-61$ & 16 & 20 \\
\hline \multicolumn{3}{|c|}{ Mean $\bar{X}=41.3$} \\
\hline \multicolumn{3}{|c|}{ Level of Education (HH Head) } \\
\hline No formal Education & 4 & 5 \\
\hline Primary & 12 & 15 \\
\hline Secondary & 48 & 60 \\
\hline Tertiary & 16 & 20 \\
\hline \multicolumn{3}{|l|}{ Mean $\bar{X}=11.6$} \\
\hline \multicolumn{3}{|l|}{ Household Size } \\
\hline $1-3$ & 20 & 25 \\
\hline $4-6$ & 32 & 40 \\
\hline $7-9$ & 16 & 20 \\
\hline $10-12$ & 12 & 15 \\
\hline \multicolumn{3}{|l|}{ Mean $\bar{X}=6$} \\
\hline \multicolumn{3}{|l|}{ Farm Size } \\
\hline $0.5-0.9$ & 32 & 40 \\
\hline $1.0-1.4$ & 20 & 25 \\
\hline $1.5-1.9$ & 19 & 23.75 \\
\hline $2.0-2.4$ & 2 & 2.50 \\
\hline $2.5-2.9$ & 7 & 8.75 \\
\hline \multicolumn{3}{|l|}{ Mean $\bar{X}=1.28$} \\
\hline \multicolumn{3}{|l|}{ Access to Credit } \\
\hline Access & 25 & 31.25 \\
\hline No Access & 55 & 68.75 \\
\hline \multicolumn{3}{|l|}{ Farming Experience } \\
\hline $4-9$ & 20 & 25 \\
\hline $10-16$ & 45 & 56.25 \\
\hline $17-22$ & 15 & 18.75 \\
\hline Mean $\bar{X}=11.85$ & & \\
\hline
\end{tabular}

Source: Field Survey, 2017 HH=Household Head

The distribution of the respondents according to access to credit showed that majority $(68.75 \%)$ had no access to credit while $31.25 \%$ had access to credit facility in the study area. The low percentage of farmers with access to credit facility could result to low access to arable land since land is needed as a security for granting credit to prospective borrowers. The farming experience of the respondents showed that majority $(56.25 \%)$ of the arable crop farmers had 10-16 years of farming experience, $25 \%$ had 49 years farming experience, while $18.75 \%$ had 17 22 years of farming experience. The mean farming experience was 11.85 implying that the respondents were experienced farmers, hence, they had over the years acquired enough farming experience needed to access the number of land needed for farming. This conformed with the work of Tsue et al. (2014), which indicated that the majority of arable crop farmers had an experience far above 10 years.

\section{Methods of Land Ownership and Acquisition}

The method of land ownership and acquisition in the study area is presented in Table 2. From Table 2, the major form of land ownership and acquisition was through inheritance $(92.5 \%)$, communal $(72.5 \%)$ and purchase $(50 \%)$. Land ownership by inheritance is prevalent and has always been a dominant form of land ownership in Africa. This is in line with Ekenta et al. (2012) who found that land inheritance was the most common ownership 
structure among male farmers while females purchased land used in agricultural production. Other forms of land acquisition as observed in the study area included; lease holding, $(26.2 \%)$, pledge (4.2\%), sharecropping (3.3\%), and grant $(2.5 \%)$.

Level of Access to Land by Arable Crop Farmers The level of access to land by arable crop farmers is shown in Table 3. The level of access to land was categorized as high, moderate, and low access respectively using the index of land access generated. The result indicates that $42 \%$ of the arable crop farmers had moderate access to the land they needed for farming, $35 \%$ had high access to the land they needed for farming, while $22 \%$ had low access to the land they needed for farming. The high percentage of farmers with moderate access to land they needed for farming suggests that not all farmers have access to arable land.

Table 2: Method of land ownership/acquisition

\begin{tabular}{lll}
\hline Method of land ownership & Frequency* & Percentage\% \\
\hline Inheritance & 74 & 92.5 \\
Communal & 58 & 72.5 \\
Purchase & 40 & 50 \\
Grant & 2 & 2.5 \\
Lease holding & 21 & 26.2 \\
Pledge & 9 & 4.2 \\
Sharecropping & 7 & 3.3 \\
Total & 211 & \\
\hline \multicolumn{2}{l}{ Source; Field Survey, 2017 Note * Multiple responses }
\end{tabular}

Table 3: Level of access to land of arable crop farmers

\begin{tabular}{llll}
\hline & Level of access & Frequency & Percentage\% \\
\hline $0.1-0.3$ & High & 28 & 35 \\
$0.4-0.6$ & Moderate & 34 & 42 \\
$0.7-1.0$ & Low & 18 & 22 \\
Total & & 80 & 100 \\
\hline
\end{tabular}

Source: Field Survey, 2017

Table 4: Logistic estimate of access to land by the arable crop farmers in the study area

\begin{tabular}{|c|c|c|c|c|}
\hline Access & Coefficient & $\begin{array}{l}\text { Standard } \\
\text { Error }\end{array}$ & $\mathrm{Z}$ & $\mathrm{P}>|\mathrm{z}|$ \\
\hline Age & 2366511 & .1164392 & 2.03 & $0.041^{*}$ \\
\hline Sex & 1.627878 & .3528659 & 4.61 & $0.000 * * *$ \\
\hline $\begin{array}{l}\text { Household } \\
\text { Size }\end{array}$ & -.221708 & .1124747 & -1.97 & $0.094 *$ \\
\hline $\begin{array}{l}\text { Years Spent } \\
\text { in School }\end{array}$ & .1729794 & .0329737 & 5.25 & $0.000 * * *$ \\
\hline $\begin{array}{l}\text { Objective of } \\
\text { Farming }\end{array}$ & .6212006 & .8248716 & 0.75 & 0.451 \\
\hline $\begin{array}{l}\text { Cooperative } \\
\text { Membership }\end{array}$ & 2.602403 & 1.388662 & 1.87 & $0.076^{*}$ \\
\hline $\begin{array}{l}\text { Farming } \\
\text { Experience }\end{array}$ & .0722917 & .0607337 & 1.19 & 0.234 \\
\hline $\begin{array}{l}\text { Annual } \\
\text { Income }\end{array}$ & $8.83 \mathrm{e}-07$ & $4.42 \mathrm{e}-06$ & 0.20 & 0.842 \\
\hline $\begin{array}{l}\text { Credit } \\
\text { Access }\end{array}$ & 1.214536 & .5745272 & 2.11 & $0.036^{*}$ \\
\hline Constant & -13.36118 & 6.00313 & -2.23 & 0.026 \\
\hline $\begin{array}{l}\text { Log } \\
\text { Likelihood }\end{array}$ & -12.895202 & & & \\
\hline $\begin{array}{l}\text { Number of } \\
\text { observation }\end{array}$ & 80 & & & \\
\hline Pseudo $\mathrm{R}^{2}$ & 0.6187 & & & \\
\hline Chi Square & $9.33 * * *$ & & & \\
\hline
\end{tabular}

Author's Computation, Stata 12 Note: * significant at $10 \%$, *** significant at $1 \%$
Determinants of Access to Land by Arable Crop Farmers in Ikwuano LGA, Abia State

The determinants of access to land by arable crop farmers in Ikwuano LGA of Abia State is presented in Table 4. Logit regression model was employed to estimate the determinants of access to land by arable crop farmers in Ikwuano, Abia state, Nigeria. The model showed a good fit with a number of significant variables with log likelihood of -12.89 and Chi Square value of $9.33 * * *$. The result showed that age, sex, household size, number of years spent in school, cooperative membership, and access to credit significantly influenced farmers' access to arable land in the study area.

The coefficient of age of the household head was positive and significantly related with access to land by arable crop farmers at $10 \%$ Level. This implies that older farmers more often than not have greater access to land for arable crop farming than younger ones. The coefficient of sex of the household was positive and significant at $1 \%$ level, thus indicating that male headed households had greater access to land for arable crop farming in the study area. This suggests existence of gender disparity in land distribution in the study area. The coefficient of household size of the respondent was negative and significant at $10 \%$ level. This implies that larger households have experience more difficulty in acquiring land for arable crop farming in the study area. Also, given the large household size of some families, available land are distributed among the large number making access to land needed for farming cumbersome.

The coefficient of number of years spent in school was positive and significant at $1 \%$ indicating that more educated farmers are more likely to have access to land for arable crop farming than less educated rural farmers. This implies that increase in the level of education leads to increased access to arable land needed for farming by the farmers in the study area. As noted by Gutu et al. (2012), household heads with higher level of education have better level of planning, access and understanding of early warning information, better decision making skills during natural shocks, alter agricultural operation and higher access to land relative to others. The coefficient of membership of co-operative society was positive and significant at $10 \%$ level of probability. Co-operatives and other similar societies play important roles in advancing the interest of the individuals and collective members and as such may help members to acquire and access arable land. The coefficient of access to credit was also positive and significant at $10 \%$ level of probability. This is in line with apriori expectation that with large farm land credit institutions are likely to lend credit to prospective farmers that may want credit to boost their production. 
Table 5 Constraints to arable land acquisition in the area

\begin{tabular}{|c|c|c|c|}
\hline Constraints & Frequency* & Percentage & Rank \\
\hline $\begin{array}{l}\text { Communal land } \\
\text { ownership }\end{array}$ & 55 & 68.75 & $1^{\text {st }}$ \\
\hline $\begin{array}{l}\text { Male superiority } \\
\text { in land sharing }\end{array}$ & 35 & 43.75 & $2^{\text {nd }}$ \\
\hline $\begin{array}{l}\text { Present land } \\
\text { ownership structure }\end{array}$ & 25 & 31.25 & $3^{\text {rd }}$ \\
\hline $\begin{array}{l}\text { Government } \\
\text { encroachment }\end{array}$ & 11 & 13.75 & $5^{\text {th }}$ \\
\hline High price of land & 10 & 12.5 & $6^{\text {th }}$ \\
\hline Cultural barrier & 5 & 6.25 & $7^{\text {th }}$ \\
\hline $\begin{array}{l}\text { Lack of collateral to access } \\
\text { credit for land purchase }\end{array}$ & 20 & 25 & $4^{\text {th }}$ \\
\hline
\end{tabular}

\section{Major Constraints to Access to Land}

Major constraints militating against land access and acquisition in the study area is presented in Table 5 The result on Table 5 shows the following perceived constraints to land access by arable crop farmers in Ikwuano LGA of Abia State: lack of collateral to access credit for land purchase $(25 \%)$, Cultural barrier $(6.25 \%)$, High price of land (12.5\%), Government encroachment (13.75\%), Present land ownership structure $(31.25 \%)$, Male superiority in land sharing $(43.75 \%)$ and communal land ownership (68.78\%). The result evidently indicates that the major constraints to access to land were communal ownership system of land and Male superiority in land sharing. This agrees with Deininger et al. (2014) who identified weak protection of rights in practice, large gaps in female land access, and limited outreach and effectiveness of institutions to record rights and adjudicate disputes as major constraints to land acquisition in 10 African countries and contrary to Adamu, (2014) who found that financial constraint and shortage of land were the main factors affecting land acquisition among the farmers in Osun State. On the other hand, male superiority in land sharing and land ownership structure adversely constraint farmer's access and use of land for agricultural purposes. This view was stressed by Nwadiaro and Okoroafor (2011) when they reported that potential farmers especially women are denied many of their fundamental rights (including access and use of land) for no other reason.

\section{CONCLUSION}

From the result it can be deduced that access to land and land distribution is skewed against women, though it was moderate for both men and women. Also majority of the respondents had no access to credit facility as a result their access to arable land and farm sizes were very low. The major method of land ownership was through inheritance and communal. It was also found that men had more access to arable land than women and that as ones age increases his/her access to land improves also. Large household size was found to be inversely related to access to land, while higher education of the farmers was found to be directly related to access to land. Farmers that belong to one or more cooperatives and had higher years of experience had more access to arable land than those that belong no-where.

\section{RECOMMENDATIONS}

- The study recommends the boosting of agricultural extension services in the area as farmers who are more educated and informed will have more access to land than otherwise.

- Local government councils should grant land use rights to both men and women in rural communities to improve their access and use of land for agricultural purposes.

- Group formation and membership should be promoted and encouraged to enhance women purchasing power through access to credit, and common voice in accessing communal lands.

\section{REFERENCES}

Adamu, C. O (2014). Land acquisition and types of crops cultivated by farmers in Ayedaade Local Government Area, Osun State, Nigeria. Asian Journal of Agricultural Extension, Economics \& Sociology 3 (6), 738-745

Bamire, A.S. (2010). Effects of tenure and land use factors on food security among rural households in the dry savannas of Nigeria, .African Journal of Food Agriculture Nutrition and Development, 10 (1), 1982-2000.

Deininger, K, Hilhorst, T and Songwe, V. (2014). Identifying and addressing land governance constraints to support intensification and land market operation: evidence from 10 African countries. Food Policy, 48, (2014) 76-87

Ekenta, C.M, Mahammed, A.B and Afolabi, K O (2012). Gender Analysis of Land Ownership Structures and Agricultural Production in Imo State, Nigeria, Journal of Economic and Sustainable Development Vol 3 (9), 67-73

Ezedinma C.I. and Oti N.N. (2001). Socio-economic issues in the development of cassava processing technology in Nigeria. Journal of Sustainable Agriculture and Environment, 3 (1),120-126

Gujarati D.N (2004). Basic Econometrics $4^{\text {th }}$ Edition. The McGraw Hill Companies

Gutu T., Emana B. and Ketema, M. (2012). Analysis of vulnerability and resilience to climate change induced shocks in North Shewa, Ethiopia. Agricultural Sciences, 3 (6), 871-888

International Fund for Agricultural Development, IFAD (2008) Improving Access to land and Tenure Security: Policy, Rome

Migot-Adholla S. and Bruce J. (1994). Introduction: Are indigenous African tenure systems insecure? pp 113 In: Bruce, J. and Migot-Adholla, S.E. (eds.). Searching for Land Tenure Security in Africa. Kendall-Hunt Publishing Company, Dubuque IA

Marie C.D., Simbizi J.Z. and Rohan B. (2014). Measuring the land tenure security of sub-Saharan Africa's rural poor. FIG Congress, 2014 Engaging the Challenges-Enhencing the Relevance. Kuala Lumpur, Malaysia 16-21 June 2014 
Mintzer Rebekah (2010). Gender Equality Stressed at Conference on Eliminating Food Insecurity

Henri-Ukoha A., Korie O.C., Ibekwe U.C., ChidiebereMark. N.M., Ejike R.D. and Okparadim G.I. (2014). Determinants of access to landholding in femaleheaded cassava farming households in Abia State, Southeast Nigeria, Journal of Biology, Agriculture and healthcare, 4 (4), 39-44

National Population Commission (2006). 2006 National Census Data for Nigeria. Abuja

Neupane R.P., K.R. Sharma and G.B. Thapa (2002). Adoption of agroforestry in the Hill of Nepal: a logistic regression Analysis. Agricultural System, 72 (3), 177-196

Nwadiaro E.C.C. and Okoroafor (2011). Gender roles and access to material and economic resources in Nigerian rural communities. Research Journal of International Studies, 1 (8), 26-33

Obamiro E., Doppler W. and Kormawa P. (2003). Pillars of food security in rural areas of Nigeria. Food Africa International Forum, $31^{\text {st }}$ March-1 $11^{\text {th }}$ April.
Retrieved on 15 March, 2011 from www.foodafrica.nri.org/security/internetpapers/

Ogunwale B. (2000). Communication channels for information dissemination on poverty alleviation among small scale farmers in Oyo State. A paper Presented at AESON Conference, University of Ibadan, Ibadan, Nigeria

Oyekale A.S. (2012). Intensive land use, land management and efficiency of food production in the Niger Delta region of Nigeria. Electronic Journal of Environmental, Agricultural and Food Chemistry, 11 (3), 188-204

Titilola S.O. and Jeje L.K. (2008). Environmental degradation and its implications for agricultural and rural development: the issue of land erosion. Journal of Sustainable Development in Africa, 10 (2), 116-146

Tsue P.T., Nweze N.J. and Okoye C.U. (2014). Effects of arable land tenure and use on environmental sustainability in North-Central Nigeria. Journal of Agriculture and Sustainability, 6 (1), 14-38 